\title{
Why relational marketing impacts on bank's customer satisfaction?
}

\section{Dedy Ansari Harahap ${ }^{*}$, Dita Amanah², and Rubayah Yakob}

${ }^{1}$ Department of Management, Faculty of Economics and Business, Universitas Islam Bandung

Jalan Tamansari, Bandung 40116, Indonesia deanhar@yahoo.com

${ }^{2}$ Department of Management, Faculty of Economics, Universitas Negeri Medan Jalan William Iskandar Ps. V, Deli Serdang 20371, Indonesia ditamnh@yahoo.com

${ }^{3}$ Finance and Risk Management \& Financial Services Programme, Faculty of Economics and Management, Universiti Kebangsaan Malaysia Jalan Raja Muda Abdul Aziz, Kuala Lumpur 50300, Malaysia rubayah@ukm.edu.my

\begin{abstract}
This study examines the impact of relational marketing to customer satisfaction with the case study on Postgraduate Students at Universitas Pendidikan Indonesia who become the customer of Bank BNI Setiabudhi, Bandung. The study aims to determine the impact of relational marketing's variables such as the level of commitment, empathy, reciprocity and trust to customer satisfaction. The research method is an explanatory research with probability sampling as the sampling method. There are 110 samples that collected through questionnaire. The samples are randomly selected and measured by Likert scale. Furthermore, the data is analyzed with Multiple Linier Regression methods. The result of study implies that the variables of relational marketing impact positively to the level of customer satisfaction. The dimension of "trust" gives the strongest effect on customer satisfaction and the dimension of "empathy" gives the weakest effect on customer satisfaction.
\end{abstract}

Keywords: bank; customers; relational marketing; satisfaction.

Received: February 8, 2019; Accepted: August 2, 2019; Published: October 17, 2019

*Corresponding author

Email: deanhar@yahoo.com

How to cite this document:

Harahap, D. A., Amanah D., dan Yakob R. (2019). Why relational marketing impacts on bank's customer satisfaction? BISMA (Bisnis dan Manajemen), 17(Oktober), 43-53.https://doi.org/10.26740/bisma.v12n.p43-53 


\begin{abstract}
Abstrak
Studi ini meneliti dampak pemasaran relasional terhadap kepuasan nasabah, menggunakan mahasiswa pascasarjana di Universitas Pendidikan Indonesia, Bank BNI Setiabudhi Bandung sebagai studi kasus. Tujuannya adalah untuk menentukan dampak pemasaran relasional terhadap kepuasan pelanggan, untuk memeriksa tingkat komitmen, empati, timbal balik dan kepercayaan mempengaruhi kepuasan nasabah. Penelitian ini menggunakan pendekatan kuantitatif dengan tipe penelitian eksplanatori. Teknik sampel yang digunakan adalah non probability sampling, jumlah sampel sebanyak 110 responden yang dipilih secara acak dan teknik pengumpulan data yang digunakan adalah kuesioner yang pengukurannya menggunakan skala likert dan analisis statistik dengan metode regresi linier berganda. Penelitian ini menemukan bahwa dimensi pemasaran relasional memiliki dampak positif terhadap tingkat kepuasan nasabah. Dimensi "kepercayaan" memiliki efek terbesar dan dimensi "empati" memiliki efek terendah pada kepuasan nasabah.
\end{abstract}

Kata kunci: bank; kepuasan; pelanggan; pemasaran relasional.

\title{
INTRODUCTION
}

The rivalry of Indonesia banks is very competitive and changing rapidly. The banks must build a strong relationship with customers to ensure a long-term profitability and sustainable core income. At present, the main marketing focus is shifting to more customers-oriented. Over the past fifteen years, major changes have occurred in the way industrial companies deal with their customers and suppliers as well as in banking industry. The company is trying to foster long-term relationships to get new customers while strengthening their relationships with existing customers (Berry, 2002). The main benefit that can be obtained from implementing relational marketing is the acquiring stronger customer relationships that intensify performance along with the sales growth, profit, customer retention, and return on investment (Morgan \& Hunt, 1994).

This condition becomes a challenge for banking businesses to improve the banking services and products themselves, how to maintain the current market and develop a wider customer's network. The higher level of competition and wider access for every company to reach its customers are the drivers of relational marketing paradigm. The study aims to determine the impact of relational marketing's variables such as the level of commitment, empathy, reciprocity, and trust to customer satisfaction.

\section{Relational Marketing}

Relational marketing has an important role in creating customer satisfaction. According to Zeithaml, Bitner, \& Gremler, (2017), "Relationship marketing is an effort to get to know customers better, so that companies can meet their needs and wants in the long run". If the needs and desires of customers have been fulfilled, the customer satisfaction is achieved. Therefore, relational marketing should be improved to create customers satisfaction and influenced them to retain a long- 
term relationship with the company which posits positive impact on company profit.

The concept of relational marketing is an interesting topic that has been studied by marketer's researchers over the past two decades (Berry, 2002; Grönroos, 1994; Morgan \& Hunt, 1994; Sheth \& Parvatiyar, 1995; Vargo, 2009). According to Zeithaml \& Bitner, (2003), "The main objective of relational marketing is to build and retain committed customers who gives benefits (profit) for the company and minimizes the time and effort spent by company on less profitable customers". According to Tanjung, (2004) the marketing dimension determine four relational marketing variables to measure the company performance. The four variables are: commitment, empathy, reciprocity, and trust.

Barnes (2003) stated that commitment is a psychological condition that generally represents the experience of dependence on a relationship, then the indicators of commitment are emotional ties, a sense of belonging, and an important relationship to be maintained. According to Tjiptono (2008), "empathy is the company's willingness to understand customer problems and provide personal attention to them and having comfortable operating hours". Furthermore, Sin, Tse, \& Yim, (2005) defined that "reciprocity" is a component of business relations that reflects the willingness of each party to need one another or reciprocate the kindness from the other party. Tanjung (2004) added that "reciprocity reflects that there shoud be a take and give in a long-term relationship. It means both sellers and buyers give benefits to each other". Meanwhile, Garbarino \& Johnson (1999) described that the notion of trust in service marketing places emphasizes on individual attitudes that refer to customer confidence in the quality and reliability of the services they received. Moreover, Peppers \& Rogers (2010) added that "the trust is a belief of one party on the reliability, durability, and integrity of the other party in the relationship and the belief that their actions are in the best interest and will create positive results for the trusted party".

According to Mowen and Minor Donavan, Minor, \& Mowen (2016), the customer satisfaction means the overall consumers attitude after obtaining and consuming goods and services. The customer satisfaction as a concept has been included into various theoretical and conceptual frameworks and models (Chan, 2003). These models or frameworks have addressed the measurement of customer satisfaction, drivers of customer satisfaction, and measurement of related variables (Keillor, Parker, \& Pettijohn, 1999). The customer satisfaction is achieved through customer experience in consuming products / services compared to their expectations. Furthermore, customer satisfaction has been defined in various ways including: the overall feeling, or attitude of consumer towards a product after purchase it (Solomon, 2009), or as a summary, affective intensity responses and variables that centered on specific aspects of acquisition and / or consumption that 
happened at the right time when consumer evaluated the objects (Giese \& Cote, 2002).

\section{Customer Satisfaction}

Customer satisfaction can be interpreted as an overall evaluation of customers on the offering performance from seller to recent date (Johnson \& Fornell, 1991). This overall evaluation highly depends on the performance of the organization and the product. However, performance to a large extent depends on the long-term friendly marketing relationship between the customer and the organization.

Based on some of terms of customer satisfaction above, it can be concluded that customer satisfaction (bank's customer) in the perspective of the bank is a comparison between bank services and the results of services received by customers should be equal to their customer expectation or even exceed it (Harahap \& Amanah, 2019). Customers experience various levels of satisfaction and dissatisfaction after experiencing each service based on the extent to which expectations are met or exceeded. Basically, customers expect to be able to obtain products that give them benefits at an acceptable price level. Therefore, to assist the customers fulfill their needs, each company tries optimally to use their assets and capabilities to provide value and meet customer expectations.

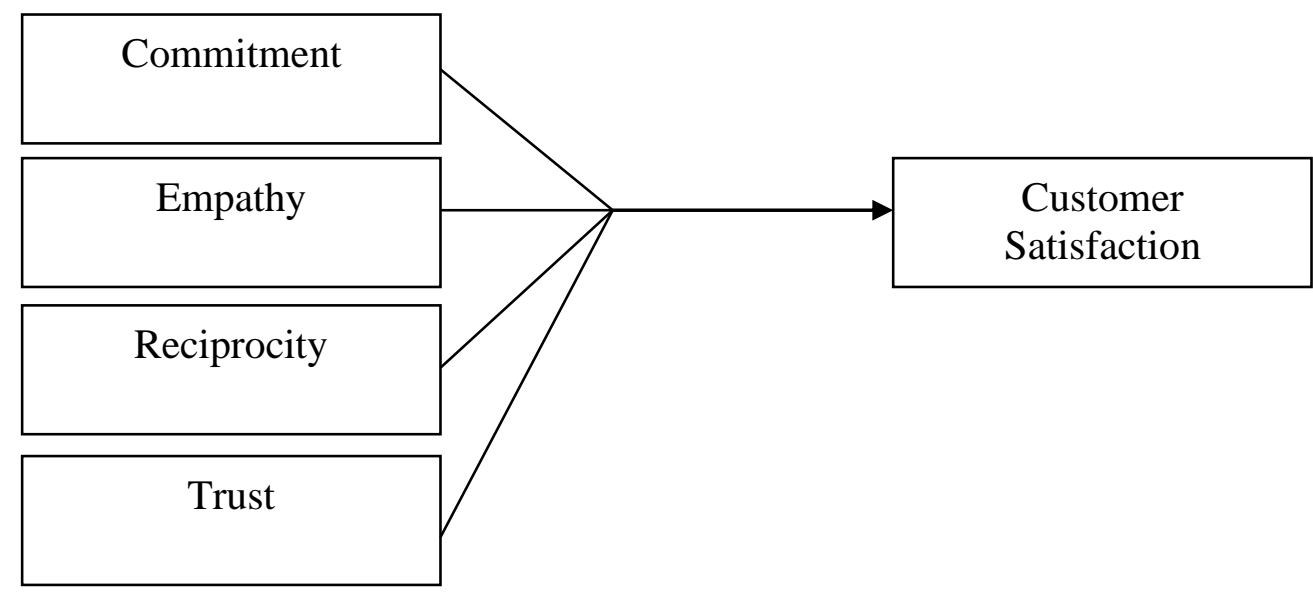

Figure 1. Conceptual Framework

\section{Hypothesis}

This hypothesis describes the relationship in the conceptual framework in Figure 1. The hypotheses in this study are:

H1: There is an influence of commitment on customer satisfaction.

$\mathrm{H} 2$ : There is an influence of empathy on customer satisfaction.

H3: There is an influence of reciprocity on customer satisfaction.

H4: There is an influence of trust on customer satisfaction.

H5: There is an influence of commitment, empathy, fe and trust on customer satisfaction. 
Page 43-53

\section{METHODS}

In this study, the primary data was obtained through several questionnaires that distributed to students who become customers of BNI Setiabudhi, Bandung. A collection of questions was prepared to identify the impact of relational marketing dimensions: commitment, empathy, reciprocity, and trust related to customer satisfaction. Each respondent answers the selected questionnaire by giving an alternative ranking on each choice made. The questions are measured by five-point Likert-scale, with the following conditions: 1 strongly disagree, 2 disagree, 3 doubt, 4 agree and 5 strongly agree. The population in this study were UPI Graduate Students who experienced transaction at BNI Setiabudhi Bandung. To obtain the right sampling frame, the non-probability sampling was chosen as a sampling technique because its appropriateness to purpose of this study. Furthermore, the respondents were randomly selected from UPI graduate students who came to the bank. The data collection method is distributing questionnaires about the impact of relational marketing to customer satisfaction. From the 120 questionnaires that distributed, only 110 of them could be used to analyzed. The quantitative approach of explanatory research type is employed in data analysis techniques. Multiple regression analysis was conducted to examine the relationship between the independent variable (relational marketing) and the dependent variable (customer satisfaction) tested on hypotheses 1-5.

\section{RESULT AND DISCUSSION \\ Validity and Reliability Test Results}

From 9 variables of commitment, all of question variable were declared valid with the r-table value of 0.361 where $r$ count $>r$-table at a significance level of 0.05 . The result of the reliability calculation by the Cronbach Alpha test in Table 1 show the results about 0.895 and this value is greater than the r-table that equal to 0.361 at a significant level of 0.05 . Therefore, it can be concluded that the instrument used in this study is a reliable questionnaire (r-count 0.895> r-table 0.361).

Meanwhile, 8 (eight) empathy variables also were declared valid where the r-count value> r-table at a significant level of 0.05 with the r-table value is 0.361 . The result of the reliability calculation by Cronbach alpha test in Table 1 shows 0.933 and this value is greater when compared to the r-table equal to 0.361 at a significant level of 0.05 . Therefore, it can be concluded that the instrument used in this study is a reliable questionnaire (r-count $0.933>$ r-table 0.361 ).

All of 5 questions about reciprocity variable items were declared valid with the value of r-table was 0.361 where the value of $r$-count $>$ r-table at a significant level of 0.05 . The result of the reliability calculation by Cronbach Alpha test in Table 1 is 0.909 and this value was greater when compared to the r-table equals to 0.361 at a significant level of 0.05 . Therefore, it can be concluded that the 
instrument used in this study is a reliable questionnaire (r-count 0.909> $\mathrm{r}$ table $0.361)$.

All of 7 (seven) items of the confidence question variable were declared valid with the value of r-table was 0.361 where the value of $r$-count $>r$-table at a significant level of 0.05 . The result of the reliability calculation by the Cronbach Alpha test in Table 1 is 0.813 and this value was greater than the r-table equals to 0.361 at a significant level of 0.05 . Therefore, it can be concluded that the instrument used in this study is a reliable questionnaire ( $\mathrm{r}$-count $0.813>\mathrm{r}$-table $0.361)$.

Table 1. Reliability Test Result

\begin{tabular}{ccc}
\hline Variable & Cronbach's Alpha & N of Items \\
\hline Commitment (X1) & .895 & 9 \\
Empathy (X2) & .933 & 8 \\
Reciprocity (X3) & .909 & 5 \\
Trust (X4) & .813 & 7 \\
Customer Satisfaction (Y) & .847 & 5 \\
\hline
\end{tabular}

Source: Result of the research.

\section{Multiple Regression Analysis}

Multiple regression models with one dependent variable, namely: Customer satisfaction (Y) and four independent variables namely: commitment (X1), Empathy (X2), Reciprocity (X3) and Trust (X4) are:

$\mathrm{Y}=\mathrm{a}+\mathrm{b} 1 \mathrm{X} 1+\mathrm{b} 2 \mathrm{X} 2+\mathrm{b} 3 \mathrm{X} 3+\mathrm{b} 4 \mathrm{X} 4+\mathrm{e}$

From the results of data processing, the regression equation formed as follows:

$\mathrm{Y}=0.452+0.297 \mathrm{X} 1+0.030 \mathrm{X} 2+0.193 \mathrm{X} 3+0.388 \mathrm{X} 4+\mathrm{e}$

Note: $\mathrm{Y}=$ Customer Satisfaction, $\mathrm{X} 1=$ Commitment, $\mathrm{X} 2=$ Empathy, $\mathrm{X} 3=$ Reciprocity, $\mathrm{X} 4=$ Constant Trust $(\alpha)$ of 0.452 implies that if there is no variable $\mathrm{X}$ then customer satisfaction is 0.452 (assuming other factors are constant). The regression coefficient $\mathrm{X} 1$ of 0.297 implies that about $1 \%$ commitment change will affect customer satisfaction (assuming other factors are constant). The regression coefficient X2 of 0.030 implies that every change in empathy about $1 \%$ will affect customer satisfaction (assuming other factors are constant). The regression coefficient X3 of 0.193 implies that every $1 \%$ mutual change will affect customer satisfaction (assuming other factors are constant). The regression coefficient X4 of 0.388 implies that every $1 \%$ change in confidence will affect customer satisfaction (assuming other factors are constant).

\section{Partial Significance Test (t test)}

T-test in this study aims to see the magnitude of the influence between the independent variables (commitment, empathy, reciprocity and trust) on the 
dependent variable (customer satisfaction) partially, while the results of the t-test can be seen in the Table 2 t-test. To obtain the magnitude of the t-table the following calculations are performed: The significance levels of $95 \%$ and alpha $5 \%$, and degrees of freedom $(\mathrm{dk})$ with the terms $\mathrm{df}=\mathrm{nk}-1$ (in this study $(\mathrm{df}=110$ 4-1 = 105). Meanwhile, the criteria of hypothesis testing are as follows: If $t-$ count> t-table, Hol is rejected and Hal is accepted and if t-count <t-table, then Hol is accepted and Ha1 is rejected.

\begin{tabular}{ccc}
\multicolumn{3}{c}{ Table 2. T Test } \\
\hline \multirow{2}{*}{ Model } & \multicolumn{2}{c}{ T Test } \\
& T count & T table \\
\hline (Constant) & 1.170 & 1.660 \\
Commitment & 2.911 & 1.660 \\
Empathy & .395 & 1.660 \\
Reciprocity & 2.366 & 1.660 \\
Trust & 3.760 & 1.660 \\
\hline Source: Result of the research.
\end{tabular}

Based on table 2, the results obtained for the commitment variable is 2.911> 1.660, then Hol is rejected and Hal is accepted. This means the hypothesis is accepted or the commitment variable significantly influences customer satisfaction. The results obtained for the empathy variable is $0.395<1.660$, then Hol is accepted and Ha1 is rejected. This means the hypothesis is rejected or the empathy variable does not significantly influence customer satisfaction. The results obtained for reciprocity variable 2.366> 1.660, then Ho1 is rejected and Ha1 is accepted. This means the hypothesis is accepted or and reciprocity variable significantly influences customer satisfaction. The results obtained are 3,760> 1,660 , then Ho1 is rejected and Ha1 is accepted. This means the hypothesis is accepted or the trust variable significantly influences customer satisfaction.

Table 3. Result of Simultaneous Significance Test F

\begin{tabular}{cccccc}
\hline Model & Sum of Squares & df & Mean Square & F & Sig. \\
\hline Regression & 10.583 & 4 & 2.646 & 26.694 & $.000^{\mathbf{b}}$ \\
Residual & 10.407 & 105 & .009 & & \\
Total & 20.991 & 109 & & & \\
a. Dependent variable: customer satisfaction & & \\
b. & Predictors: (constant), commitment, emphaty, reciprocity, trust. \\
\hline
\end{tabular}

Source: Result of The Research

The hypothesis testing was done by comparing the value of $\mathrm{F}$ with F-table, with the following criteria, if F-count> F-table, then Ho is rejected and $\mathrm{Ha}$ is accepted, and if F-count <F-table, then $\mathrm{HO}$ is accepted and Ha rejected. Based on Table 3, the F number of the study obtained from the calculation results is 26,694 . While the $\mathrm{F}$ table is calculated by the formula df $1=\mathrm{k}-1$; df $2=\mathrm{n}-\mathrm{k}-1(4 ; 105)$ is 2.46. With these provisions, the F-table $=2.46$ is obtained. Thus, it obtained Fcount $=26.694$ and Ftable $=2.46$. Because Fcount $>$ Ftable means that Ho is 
rejected and $\mathrm{Ha}$ is accepted, so it can be concluded that commitment, empathy, reciprocity and trust have a positive and significant effect on customer satisfaction.

The results of data processing indicate that an $\mathrm{R}$ value of 0.505 means it has a strong relationship. The value of $\mathrm{R}$ square (R2) is 0.505 or $50.50 \%$ means that the influence of the independent variable (commitment, empathy, reciprocity, and trust) on the dependent variable (customer satisfaction) is $50.50 \%$ and the rest $49.50 \%$ is influenced by the other variable.

\section{Discussion}

The results of the study indicate that partially each variable of commitment influence significantly while positive empathy does not significantly influence to customer satisfaction. Then, the reciprocity and trust are significantly influence to the customer satisfaction. Meanwhile, the relational marketing (relationship marketing) that consists of commitment, empathy, reciprocity and trust dimensions are positively influence customer satisfaction at BNI Bank Setiabudhi Bandung.

Based on the research result, the customer satisfaction is influenced by relational marketing conducted by banks. It shows that the marketing strategy implemented through relational marketing by BNI Setiabudhi Bandung able to provide satisfaction to its customers. The marketing strategy that carried out by the bank makes customers feel satisfied, more trust to the bank, and customers become confident to the company's relationship with its customers. The results of this study supported the previous research of Synathra \& Sunarti, (2018), that relationship marketing has a direct effect on customer satisfaction. It also supports Sefesiyani, DH, \& Arifin, (2015) research, that there is a significant influence between relationship marketing (relationship marketing) on customer satisfaction.

The other article that investigate the relationship of relational marketing with customer satisfaction and customer loyalty of Ghavamin Bank in Sistan and Baluchistan provinces showed that there was a positive and significant relationship between the dimensions of relationship marketing with customer satisfaction and loyalty (Sayed \& Moghadam, 2015). According to Ibojo \& Dunmade (2016), the relational marketing influences consumer satisfaction to a great extent. Therefore, financial and non-financial sectors are needed to embrace and incorporate relationship marketing in their management portfolio. Therefore, BNI Setiabudhi Bandung must always evaluate its marketing strategy at any time through relational marketing, so that it will be implemented effectively in building long term relationships long and higher customer satisfaction.

\section{CONCLUSION}

The results of the study imply that partially, each positive commitment variable has a significant effect in which positive empathy has no significant 
effect. Positive reciprocity significantly influences customer satisfaction and trust positively influences customer satisfaction. Meanwhile, simultaneously relational marketing (relationship marketing) that consisting of; commitment, empathy, reciprocity and trust dimensions are positively influence customer satisfaction at BNI Bank Setiabudhi Bandung. By knowing the extent of the relational marketing that has been carried out to the customer, the bank can identify the factors that make the customer feel satisfied, so that the bank can maintain good performance and improve the underperformed aspects based on customer assessment to improve their services in the future.

The study limitation is the sample category that only limited to students who ever having transaction in BNI Setiabudhi Bandung and an insufficient number of samples that considered unrepresentative. Therefore, the researcher recommends the further research to selecting the sample from more than one bank and adding more samples so that the expected results can be generalized and able to provide more accurate results.

\section{REFERENCES}

Barnes, J. G. (2003). Secrets of Customer Relationship Management (Rahasia Manajemen Hubungan Pelanggan) (Edisi 2). Yogyakarta: Andi.

Berry, L. L. (2002). Relationship marketing of services perpectives from 1983 and 2000. Journal of Relationship Marketing, 1(1), 59-77. https://doi.org/10.1300/J366v01n01

Chan, S. (2003). Relationship Marketing. Jakarta: PT. Gramedia Pustaka Utama.

Donavan, T., Minor, M. S., \& Mowen, J. C. (2016). Consumer Behavior. Chicago: Business Press.

Garbarino, E., \& Johnson, M. S. (1999). The Different Roles of Satisfaction, Commitment in Customer Relationship. Journal of Marketing, 63(2), 70-87. https://doi.org/10.2307/1251946

Giese, J. L., \& Cote, J. A. (2002). Defining Customer Satisfaction. Marketing Science Review, 2000(1), 1-24. https://doi.org/10.1111/j.13652850.2008.01371.x

Grönroos, C. (1994). From Marketing Mix to Relationship Marketing: Towards a Paradigm Shift in Marketing. Management Decision, 32(2), 4-20. https://doi.org/10.1080/106351501753462849

Harahap, D. A., \& Amanah, D. (2019). Studi Kepuasan Nasabah PT. Bank Negara Indonesia (Persero), Tbk Kantor Cabang Pembantu UPI Bandung. Jurnal Manajemen Dan Bisnis: Performa, 16(1), 29-38. https://doi.org/https://doi.org/10.29313/performa.v16i1.4610 29 
Ibojo, B. O., \& Dunmade, E. O. (2016). Impact of relationship marketing on customer satisfaction: a case study of undergraduate students in a private university, Oyo state, Nigeria. International Journal of Economics, Commerce and Management, 4(2), 668-708. https://doi.org/http://dx.doi.org/10.1016/S1090-3798\%2811\%2970225-2

Johnson, M. D., \& Fornell, C. (1991). A Framework for Comparing Customer Satisfaction across Individuals and Product Categories. Journal of Economic Psychology, 12(2), 267-286.

Keillor, B. D., Parker, R. S., \& Pettijohn, C. E. (1999). Sales force performance satisfaction and aspects of relational selling: Implications for sales managers. Journal of Marketing Theory and Practice, 7(1), 101-115. https://doi.org/10.1080/10696679.1999.11501824

Morgan, R. M., \& Hunt, S. D. (1994). Theory of Relationship Marketing. Journal of Marketing, 58(3), 20-38.

Peppers, D., \& Rogers, M. (2010). Managing Customer Relationships: A Strategic Framework. John Wiley \& Sons.

Sayed, E. N., \& Moghadam, K. S. (2015). The Study of Relationship Marketing with Customer Satisfaction and Loyalty (Case Study: Customers of Ghavamin Bank in Sistan and Baluchestan Province). International Journal of Innovation and Research in Educational Sciences, 2(2), 96-101.

Sefesiyani, A., DH, A. F., \& Arifin, Z. (2015). Pengaruh Relationship Marketing (Pemasaran Relasional) Terhadap Kepuasan Nasabah Serta Dampaknya Pada Loyalitas Nasabah. Jurnal Administrasi Bisnis (JAB), 28(2), 1-8.

Sheth, J. N., \& Parvatiyar, A. (1995). The Future of Relationship Marketing. International Business Review, 4(4), 397-418. https://doi.org/10.1108/08876040210447324

Sin, L. Y. M., Tse, A. C. B., \& Yim, F. H. K. (2005). CRM conceptualization and scale development. European Journal of Marketing, 39(11), 1264-1290.

Solomon, M. R. (2009). Marketing: Real People, Real Decisions. Prentice Hall.

Synathra, V., \& Sunarti. (2018). Pengaruh Relationship Marketing Terhadap Kepuasan Nasabah dan Dampaknya Pada Loyalitas Nasabah (Survei pada Nasabah Tabungan BCA Kantor Kas Sawojajar Kota Malang). Jurnal Administrasi Bisnis (JAB), 55(1), 115-124.

Tanjung, W. (2004). Marketing Management Pendekatan Pada Nilai-Nilai Pelanggan. Malang: Banyumedia Publishing.

Tjiptono, F. (2008). Strategi Bisnis Pemasaran. Yogyakarta: Andi. 
BISMA (Bisnis dan Manajemen)

Volume 12 Issue 1, October 2019

E-ISSN 2549-7790, P-ISSN 1979-7192

Page 43-53

Vargo, S. L. (2009). Toward a transcending conceptualization of relationship: A service-dominant logic perspective. Journal of Business and Industrial Marketing, 24(5), 373-379. https://doi.org/10.1108/08858620910966255

Zeithaml, V. A., \& Bitner, M. J. (2003). Services Marketing: Integrating Customer Focus Across the Firm. McGraw-Hill/Irwin.

Zeithaml, V. A., Bitner, M. J., \& Gremler, D. (2017). Services Marketing: Integrating Customer Focus Across the Firm (7th Edition). New York: McGraw-Hill Education. 